AL IBTIDA: JURNAL PENDIDIKAN GURU MI (2017) VOL. 4(2): 153-164

DOI: http://dx.doi.org/10.24235/al.ibtida.snj.v4i2.1727

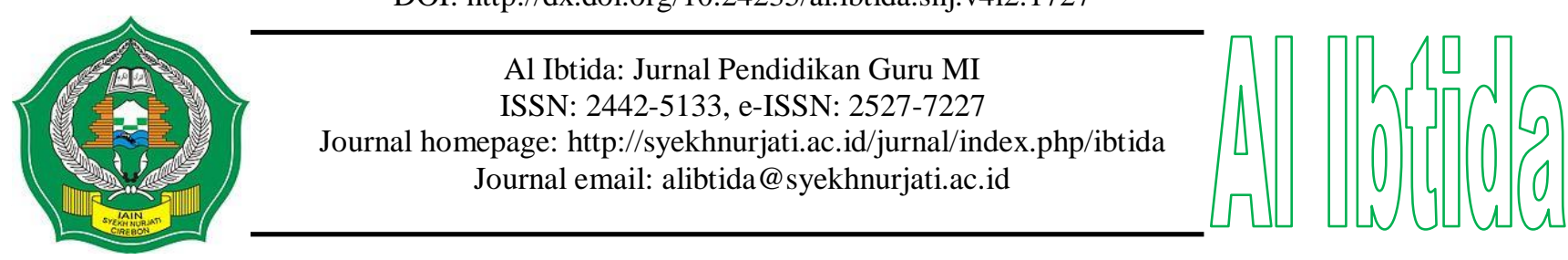

\title{
Implementasi Multi-Directional Circle Model \\ dalam Mewujudkan Madrasah Ibtidaiyah Adiwiyata di Kabupaten Magelang
}

\author{
Ahwy Oktradiksa* \\ *Program Studi Pendidikan Guru Madrasah Ibtidaiyah, Fakultas Agama Islam, \\ Universitas Muhammadiyah Magelang \\ Email: ahwy@umml.ac.id \\ Kanthi Pamungkas Sari** \\ ** Program Studi Pendidikan Guru Madrasah Ibtidaiyah, Fakultas Agama Islam, \\ Universitas Muhammadiyah Magelang \\ Email: kpamungkassari@ummgl.ac.id
}

Received 31 July 2017; Received in revised form: 18 September 2017; Accepted 25 September 2017

Publish Online: 27 October 2017

\begin{abstract}
Abstrak
Penelitian tentang implementasi model multi directional circle ini diarahkan untuk mewujudkan Madrasah Ibtidaiyah Adiwiyata di Kabupaten Magelang, yang dilaksanakan di Madrasah Ibidaiyah Muhammadiyah Jagalan. Metode penelitian yang digunakan adalah penelitian tindakan dengan menggunakan model multi directional circle dengan teknik pengumpulan data focus group discussion (FGD). Adapun hasil penelitiannya adalah: a) proses implementasi model multi directional circle dalam mewujudkan Madrasah Ibtidaiyah Adiwiyata sangat efektif karena dengan model ini dapat menggugah semangat kerja sama Madrasah Ibtidaiyah Muhammadiyah Jagalan dengan mengembangkan potensi keunggulan di bidang non akademik untuk semua komponen sekolah (kepala Madrasah, guru Madrasah, Kepemimpinan siswa Madrasah Ibtidaiyah, Komite Pemangku Kepentingan, Badan Lingkungan Hidup Magelang) menuju Madrasah Adiwiyata. b) untuk mewujudkan model madrasah ibtidaiyah adiwiyata yaitu dengan melakukan workshop menuju madrasah adiwiyata yang dibuktikan dengan ditandatanganinya Deklarasi "Piagam Madrasah Adiwiyata" dengan berbagai pihak yang berkepentingan, seperti (Program Studi PGMI UM Magelang, ketua cabang Muhammadiyah, kepala Madrasah Ibtidaiyah Jagalan) dengan melakukan pernyataan bersedia mengikuti program Madrasah Adiwiyata dan terus berkomitmen menjaga kelestarian lingkungan, terutama di lingkungan madrasah menuju madrasah adiwiyata.
\end{abstract}

Kata kunci: model lingkaran multi arah, madrasah adiwiyata. 


\begin{abstract}
The study implementation of Multi-directional Circle Model in embodying the Madrasah Ibtidaiyah Adiwiyata in Magelang Regency, which was held at the Madrasah Ibidaiyah Muhammadiyah Jagalan. Research methods used are (action research) using the method of Multi-directional circle models with data collection techniques Focus Group Discussion (FGD). As for the results of the research are: a) the process of implementation of the Multi-directional circle models in embodying the Madrasah Ibtidaiyah Adiwiyata is very effective because with the model with the evocative spirit of Madrasah Ibtidaiyah co-operation of Muhammadiyah circulation Jagalan to develop the potential for excellence in non-academic fields for all components of school (head of the Madrasah, Madrasah Teachers, Student Leadership branch of Madrasah Ibtidaiyah, Stakeholders Committee, Environmental Agency of Magelang) to Madrasah Adiwiyata. b) Multi-directional circle execution results in realizing the Madrasah Ibtidaiyah Adiwiyata Model is to do a workshop toward the Madrasah adiwiyata as evidenced by the signing of the Declaration of a "Charter of Madrasah Adiwiyata" Towards known various interested parties such as the (Study Program PGMI UMMagelang, head of the branch of Muhammadiyah, head of Muhammadiyah Madrasah Ibtidaiyah Jagalan) with do statements willing to Madrasah Adiwiyata program continue with committed to maintaining environmental sustainability, especially in Madrasah environment toward the Madrasah "eco-school".
\end{abstract}

Keywords: multi-directional circle models, eco-school.

\title{
PENDAHULUAN
}

Lingkungan dan manusia merupakan dua unsur yang saling terkait dan tak terpisahkan. Untuk bertahan hidup, manusia harus memenuhi kebutuhan primer seperti sandang, pangan dan papan. Cepatnya pertumbuhan populasi, maka kebutuhan primer mengalami peningkatan. Di samping itu, aktivitas manusia yang menghasilkan limbah domestik (rumah tangga) semakin bertambah. Menurut Pratomo dan Lili Barlia (2006) mengemukakan bahwa perubahan lingkungan hidup akibat pertumbuhan populasi dapat mengancam kehidupan. Manusia dengan alam mempunyai hubungan timbal balik, manusia memperoleh manfaat dan resiko dari alam semesta, begitu pula sebaliknya. Dalam hubungan ini seringkali nafsu manusia mendominasi akal sehat sehingga sering terjadi bencana yang bersumber dari kelalaian dalam menjaga lingkungan. Sebagaimana firman Allah SWT dalam QS. Ar-ruum: 41 berikut ini:

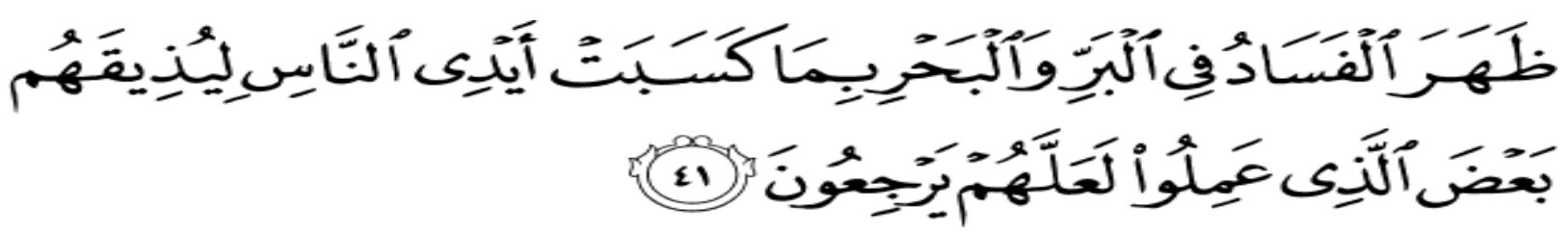

Artinya: "Telah nampak kerusakan di darat dan di laut disebabkan karena perbuatan tangan manusia, supaya Allah merasakan kepada mereka sebagian dari (akibat) perbuatan mereka, agar mereka kembali (ke jalan yang benar)." 
Bahwa penyebab kerusakan di muka bumi tiada lain adalah ulah perbuatan manusia itu sendiri. Adanya keserakahan dan kurangnya kesadaran menyayangi alam membuat manusia berbuat sewenang-wenang, seakan sumber daya yang ada tak akan pernah habis. Menurut Desfandi (2015), dalam rangka menghadapi tantangan lingkungan di bumi, ada kebutuhan untuk mendidik dan memberi informasi kepada masyarakat mengenai permasalahan lingkungan. Ditambahkan oleh Sibel, dkk (2012) salah satu komitmen masyarakat dan pemerintah internasional dalam menjaga bumi dari pencemaran dan kerusakan adalah melalui pelaksanaan Pendidikan Lingkungan Hidup (PLH)/ (Environment Education), yang merupakan kunci untuk mempersiapkan masyarakat dengan pengetahuan, keahlian, nilai dan sikap peduli lingkungan sehingga dapat berpartisipasi aktif dalam memecahkan masalah lingkungan.

PLH menurut konvensi UNESCO di Tbilisi (1997) merupakan suatu proses yang bertujuan untuk menciptakan suatu masyarakat dunia yang memiliki kepedulian terhadap lingkungan dan peduli terhadap masalah-masalah yang terkait di dalamnya serta memiliki pengetahuan, motivasi, komitmen, dan keterampilan untuk bekerja, baik secara perorangan maupun kolektif dalam mencari alternatif atau memberi solusi untuk menghindari timbulnya masalah-masalah lingkungan hidup baru. Akan tetapi berbagai masalah lingkungan yang semakin tak terkendali menunjukkan bahwa PLH belum berhasil membentuk karakter manusia yang peduli terhadap lingkungan. Kegagalan tersebut terjadi karena adanya sejumlah kelemahan dalam Pendidikan Lingkungan Hidup.

Menurut Sungkowo (2005) kegagalan tersebut tidak lepas dari hal-hal berikut: pertama, masih rendahnya partisipasi masyarakat untuk berperan dalam pendidikan lingkungan hidup, karena kurangnya pemahaman terhadap permasalahan pendidikan lingkungan, rendahnya tingkat kemampuan atau keterampilan, dan rendahnya komitmen masyarakat dalam menyelesaikan permasalahan tersebut. Kedua, pemahaman pelaku pendidikan masih terbatas. Dalam jalur pendidikan formal, masih ada anggapan bahwa pendidikan lingkungan hidup tidak begitu penting. Ketiga, materi dan metode pelaksanaan pendidikan lingkungan hidup dirasakan belum memadai dan kurang aplikatif, sehingga pemahaman kelompok sasaran mengenai pelestarian lingkungan hidup menjadi tidak utuh. Keempat, sarana dan prasarana dalam pendidikan lingkungan hidup belum mendapat perhatian yang cukup. Sarana dan prasarana untuk pendidikan lingkungan hidup sering kali disalahartikan sebagai sarana fisik yang berteknologi tinggi sehingga menjadi faktor penghambat tumbuhnya motivasi dalam pelaksanaan Pendidikan Lingkungan Hidup. Kelima, kurangnya kemampuan pemerintah untuk mengalokasikan dan meningkatkan anggaran pendidikan lingkungan, sehingga pelaksanaan PLH di berbagai instansi tidak maksimal. Keenam, lemahnya koordinasi antar instansi terkait dan para pelaku pendidikan menyebabkan kurang berkembangnya Pendidikan Lingkungan Hidup. Hal ini terlihat pada 
gerakan PLH (formal dan nonformal/informal) yang masih bersifat sporadis, tidak sinergis dan saling tumpang tindih.

Untuk membangun kesadaran dan kecintaan yang lebih mendalam terhadap pelestarian alam, pemerintah telah mencanangkan program yang disebut Sekolah Adiwiyata (Eco-School). Tujuan Program Adiwiyata adalah mewujudkan warga sekolah yang bertanggung jawab dalam upaya perlindungan dan pengelolaan lingkungan hidup melalui tata kelola sekolah yang baik untuk mendukung pembangunan berkelanjutan. Adiwiyata diterapkan dalam dunia pendidikan dikarenakan dalam dunia pendidikan lebih mudah mempelajari dan menerapkan segala ilmu pengetahuan dan berbagai norma serta etika untuk mencapai cita-cita pembangunan berkelanjutan.

Di lain pihak, Peraturan Menteri Negara Lingkungan Hidup Nomor 02 tahun 2009 tentang Pedoman Pelaksanaan Program Adiwiyata belum dapat menjawab kendala yang dihadapi daerah, khususnya bagi sekolah yang melaksanakan program Adiwiyata. Hal tersebut terutama kendala dalam penyiapan dokumentasi terkait kebijakan dan pengembangan kurikulum serta, sistem evaluasi dokumen dan penilaian fisik. Dari kendala tersebut di atas,maka dianggap perlu untuk dilakukan penyempurnaan Buku Panduan Pelaksanaan Program Adiwiyata 2012 yang dibuat oleh Tim Adiwiyata Tingkat Nasional dan sistem pemberian penghargaan yang tetap merujuk pada kebijakan-kebijakan yang telah ditetapkan Kementerian Lingkungan Hidup dan Kemendikbud. Oleh karenanya diharapkan sekolah yang berminat mengikuti program Adiwiyata tidak merasa terbebani, karena sudah menjadi kewajiban pihak sekolah memenuhi Standar Pendidikan Nasional sebagaimana dilengkapi dan diatur dalam Peraturan Menteri Pendidikan Nasional No. 19 tahun 2005, yang dijabarkan dalam 8 standar pengelolaan pendidikan.

Berdasarkan Peraturan Menteri Negara Lingkungan Hidup Nomor 05 tahun 2013 tentang Pedoman Pelaksanaan Program Adiwiyata, dalam pasal 1 ayat 1 berbunyi: sekolah adiwiyata adalah sekolah yang peduli dan berbudaya lingkungan. Ayat 2 berbunyi: Program Adiwiyata adalah program untuk mewujudkan sekolah yang peduli dan berbudaya lingkungan. Program adiwiyata mempunyai makna sebagai tempat yang baik dan ideal di mana dapat diperoleh segala ilmu pengetahuan dan berbagai norma serta etika yang dapat menjadi dasar manusia menuju terciptanya kesejahteraan hidup menuju kepada cita-cita pembangunan berkelanjutan. Tujuan program Sekolah Adiwiyata/ Eco-School adalah mewujudkan warga sekolah yang bertanggung jawab dalam upaya perlindungan dan pengelolaan lingkungan hidup melalui tata kelola sekolah yang baik untuk mendukung pembangunan berkelanjutan. Dengan melaksanakan program Adiwiyata akan menciptakan warga sekolah, khususnya peserta didik yang peduli dan berbudaya lingkungan, sekaligus mendukung dan mewujudkan sumberdaya manusia yang memiliki 
karakter bangsa terhadap perkembangan ekonomi, sosial, dan lingkungannya dalam mencapai pembangunan berkelanjutan di daerah.

Menurut Muhaimin (2002), Madrasah sebagai sekolah formal yang berciri khas agama Islam, memiliki kurikulum yang berbeda dengan sekolah biasa. Pada pendidikan madrasah mata pelajaran agama Islam dibagi ke dalam beberapa sub mata pelajaran, yakni Al-Qur'an-Hadist, Aqidah Akhlak, Fiqh, Sejarah Islam, dan Bahasa Arab, sehingga porsi pelajaran agama lebih banyak. Sementara pendidikan umum, menggabungkan mata pelajaran agama ke dalam susunan yang lebih ringkas dan rata-rata diajarkan dua jam per-minggu. Ditambahkan lagi oleh Muhaimin (2009) bahwa perbedaan mencolok antara madrasah dan sekolah umum terletak pada lebihnya alokasi waktu untuk pengajaran agama. Sebagai lembaga pendidikan swasta, madrasah memiliki fleksibilas dalam mengatur dirinya karena madrasah dibentuk untuk menjawab kegelisahan dan kebutuhan masyarakat (muslim). Madrasah tidak hanya memiliki satu wajah tetapi memiliki beberapa model berbeda dengan satu nafas yang sama, yaitu membawa ciri khas keislaman.

Madrasah Ibtidaiyah Jagalan terletak di Dusun Jagalan, Desa Salam Kecamatan Salam Kabupaten Magelang, memiliki visi: Mewujudkan Madrasah yang dapat membentuk generasi yang berkarakter, religius, disiplin, kerja keras dan peduli terhadap lingkungan hidup. Adapun misinya: a) menciptakan Madrasah yang religius, b) menciptakan lingkungan belajar yang disiplin dan terarah, c) memberdayakan seluruh potensi peserta didik dengan bekerja keras, sehingga menghasilkan lulusan yang berkompeten serta peduli terhadap lingkungan hidup. MI Muhammadiyah Jagalan sudah terakreditasi "A" sejak tahun 2017. MI ini memiliki kepedulian terhadap pemeliharaan lingkungan hidup, diantaranya adalah menanam pohon dan buah-buahan di lingkungan Madrasah. Namun, sejauh ini penanaman pohon masih bersifat konvensional tanpa didasari tujuan dan filosofi yang jelas, sehingga warga sekolah kurang mendapatkan makna mendalam akan kecintaan pada lingkungan. Oleh karena itu, perlu dilakukan pengujian dan evaluasi pelaksanaan program sekolah adiwiyata di MI Muhammadiyah Jagalan.

\section{METODE PENELITIAN}

Penelitian ini merupakan penelitian tindakan (action research). Alasan yang mendasari dalam memilih desain ini, karena dipandang sebagai upaya penggunaan metode baru untuk mengimplementasikan multi-directional circle model dalam mewujudkan Sekolah Adiwiyata di Madrasah ibtidaiyah. Selama ini program Sekolah Adiwiyata dilaksanakan secara konvensional sehingga hasilnya kurang optimal, sehingga perlu diadakan pengujian dan evaluasi dengan siklus-siklus tertentu. Penelitian tindakan berfungsi mengumpulkan informasi secara sistematis sehingga menghasilkan perubahan sosial. 
Penelitian ini diilustrasikan dengan diagram alir di bawah ini:

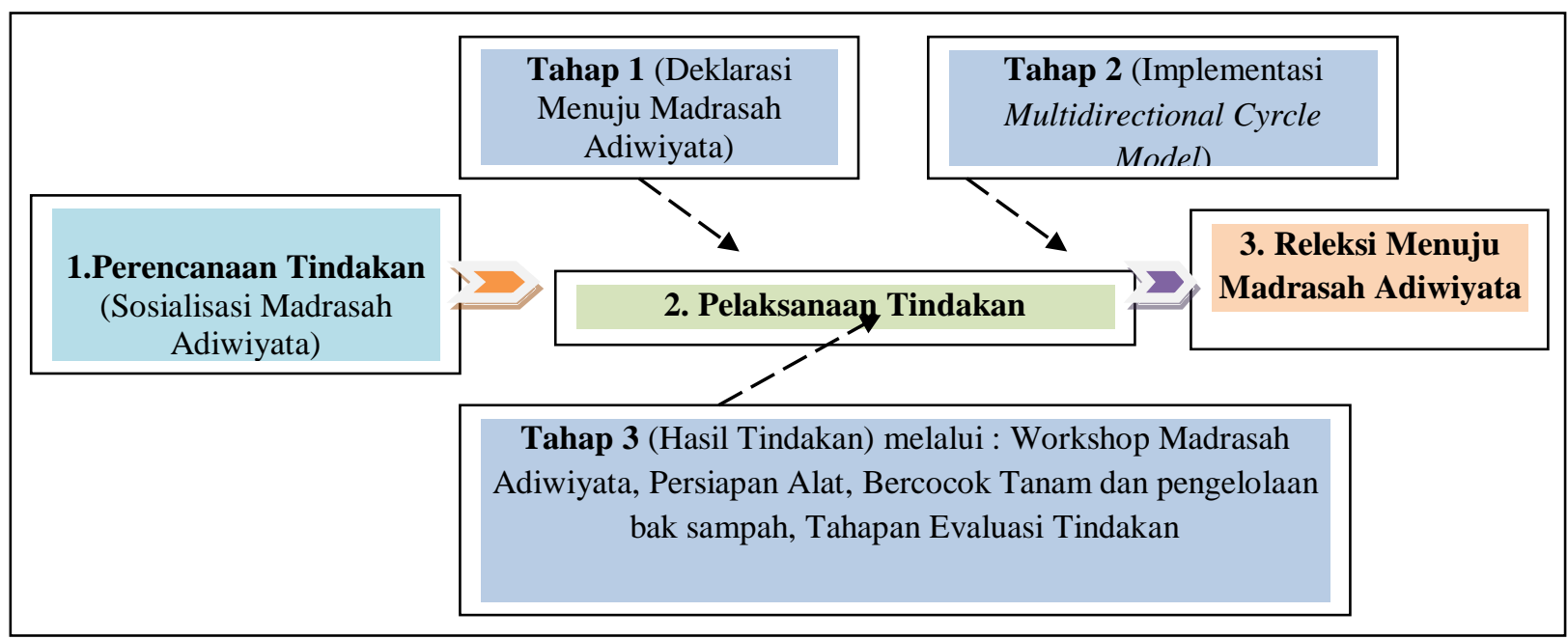

Gambar 1. Siklus Tahapan Penelitian

Secara terperinci tahapan-tahapan dalam rancangan penelitian ini adalah sebagai berikut:

1. Kegiatan perencanaan, meliputi: a) sosialisasi atau workshop program sekolah adiwiyata kepada siswa, guru, karyawan dan komite sekolah kerjasama dengan Kantor Lingkungan Hidup Kabupaten Magelang; b) focus group discussion (FGD) tentang persepsi dari obyek sosialisasi tentang program sekolah adiwiyata. Selanjutnya dilakukan assesment terkait dengan persepsi dari obyek sosialisasi; c) FGD yang dilaksankan untuk menyusun tugas pokok masing-masing elemen yang terlibat untuk mewujudkan Sekolah Adiwiyata; d) membuat perencanaan program-program terkait dan juga menetapkan target waktu dan target kinerja dari setiap tugas pokok masing-masing elemen terkait dan disesuaikan dengan kondisi obyektifnya; d) membuat dan melengkapi alat-alat yang mendukung kegiatan; f) membuat desain alat evaluasi kegiatan; dan g) membuat lembar evaluasi kegiatan.

2. Pelaksanaan Tindakan, yakni melaksanakan semua kegiatan-kegiatan yang telah direncanakan sesuai dengan target waktu dan target kinerja dari masing-masing elemen terkait, dalam hal ini adalah: pemerintah, komite sekolah, guru, karyawan dan siswa.

3. Observasi, dalam tahap ini dilaksanakan observasi terhadap pelaksanaan tindakan dengan menggunakan lembar evaluasi yang telah disiapkan.

4. Refleksi, berdasarkan hasil observasi tersebut peneliti dapat merefleksi diri tentang kegiatan penerapan multi-directional circlemodel yang telah dilakukan. Dengan demikian peneliti akan dapat mengetahui ketercapaian target-target yang telah ditetapkan atau efektifitas kegiatan pemberdayaan masyarakat dengan menggunakan multi-directional circle model. Berdasarkan hasil refleksi ini akan diketahui kendala atau kelemahan kegiatan sehingga dapat digunakan untuk menentukan perencanaan tindakan selanjutnya (tahapan berikutnya) 
dengan maksud menyempurnakan hasil yang hendak dicapai. Siklus akan berhenti apabila berada pada kondisi data jenuh.

\section{HASIL DAN PEMBAHASAN}

Dalam Jurnal Administrasi Publik, Rahmah (2015) menyatakan bahwa untuk membangun kesadaran dan kecintaan yang lebih mendalam terhadap pelestarian alam, pemerintah telah mencanangkan program yang disebut Sekolah Adiwiyata (Eco-School) dengan tujuan untuk mewujudkan warga sekolah yang bertanggung jawab dalam upaya perlindungan dan pengelolaan lingkungan hidup melalui tata kelola sekolah yang baik untuk mendukung pembangunan berkelanjutan. Adiwiyata diterapkan dalam dunia pendidikan disebabkan dalam dunia pendidikan lebih mudah mempelajari dan menerapkan segala ilmu pengetahuan dan berbagai norma serta etika untuk mencapai cita-cita pembangunan berkelanjutan.

Hasil penelitian ini menggambarkan hubungan kerjasama yang fungsional antara komite sekolah, guru, karyawan dan siswa dalam melaksanakan berbagai program adiwiyata. MI Muhammadiyah sebagai obejek penelitian sudah memenuhi persyaratan sebagai sekolah yang sudah siap untuk dijadikan Madrasah pertama pada jenjang pendidikan dasar di Kabupaten Magelang sehingga dalam prakteknya masing-masing elemen mempengaruhi elemen yang lain dan mempunyai peran atau kontribusi sesuai dengan fungsinya. Misalnya peran Komite Sekolah sebagai pengarah, motivator dan dinamisator yang menghubungkan kedua elemen tersebut dengan pihak-pihak luar dalam rangka mendukung terlaksananya program Adiwiyata, sebagaimana menurut Carly (2009) sekolah adiwiyata yang berpartisipasi, menerapkan tujuh langkah untuk menuju sertifikasi Green Flag, meskipun terdapat variasi dalam isi dan fokus dari langkah-langkah yang dilakukan adalah untuk 1) memperbaiki lingkungan sekolah, 2) mengurangi sampah dan limbah, 3) mengurangi penggunaan energi dan air, 4) menemukan caracara yang efisien perjalanan ke dan dari sekolah, 5) mempromosikan gaya hidup sehat, 6) mendorong kewarganegaraan aktif, dan 7) membangun kemitraan yang kuat dengan berbagai kelompok masyarakat.

Adapun metode penelitian yang digunakan sangatlah mendukung integrasi yaitu guru menyelipkan masalah peduli lingkungan pada hampir semua mata pelajaran yang diberikan, mengembangkan kegiatan peduli lingkungan berbasis partisipatif. Karyawan melakukan peran sebagai pengelola sarana pendukung berbasis lingkungan, dan siswa memiliki peran sebagai penjaga agar lingkungan tetap bersih, hemat sumber daya, dan memiliki kepekaan rasa untuk memperbaiki lingkungan yang rentan rusak. Sehingga masing-masing elemen sekolah yang terlibat setelah mengetahui peran dan fungsinya masing-masing mereka melakukan perencanaan 
dengan target-target capaian yang jelas. Selanjutnya dalam proses pelaksanaan kegiatan yang direncanakan dilakukan monitoring dan evaluasi oleh pihak-pihak yang disepakati.

Hubungan antara ketiga elemen tersebut selanjutnya disebut multi-directional circle model yang digambarkan sebagai berikut:

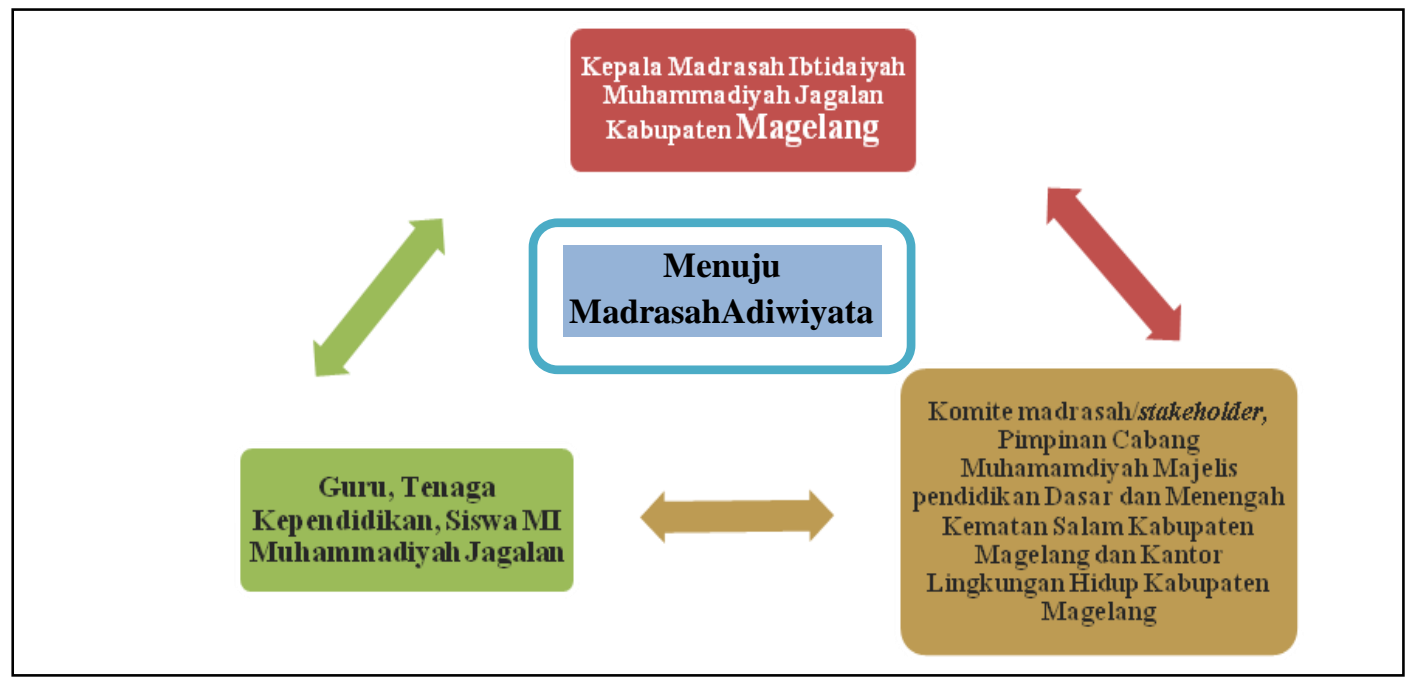

Gambar 2. Multi-directional circle Model

\section{Implementasi Tahapan dalam Siklus}

\section{Rencana tindakan (deskripsikan skenario pembelajaran)}

MI Muhammadiyah Jagalan Kabupaten Magelang adalah sekolah dasar yang belum mengaplikasikan sistem keunggulan non-akademik berupa program sekolah Adiwiyata sehingga untuk mendorong MI Muhammadiyah Jagalan membutuhkan komitmen untuk mewujudkan keberhasilannya. Sehingga implementasi skrenario pembelajaran dibutuhkan sosialisasi melalui workshop pendampingan berbagai pihak. Adapun pihak yang dilibatkan: 1) warga sekolah (kepala madrasah, guru dan siswa), 2) peneliti dan dibantu oleh pakar sekolah adiwiyata (Dosen Universitas Muhammadiyah Magelang), 3) komite madrasah /Stakeholder /Pimpinan Cabang Muhammadiyah (PCM) Salam Kabupaten Magelang yang berkepentingan dalam pengembangan program pendidikan melalui Majelis Pendidikan Dasar dan Menengah.

\section{Pelaksanaan Tindakan}

Tahap 1 (Deklarasi Menuju Madrasah Adiwiyata)

Pelaksanaan program Madrasah Adiwiyata terdiri dari 4 (empat) program, yang meliputi :

a. Kebijakan berwawasan lingkungan : visi dan misi, implementasi kurikulum sekolah; harus siap untuk diintegrasikan dengan memuat upaya perlindungan dan pengelolaan lingkungan hidup, Rancangan Kerja Anggaran Sekolah (RKAS); memuat program dalam upaya perlindungan dan pengelolaan lingkungan hidup. 
b. Pelaksanaan kurikulum berbasis lingkungan: tenaga pendidik; harus mempunyai kompetensi dalam mengembangkan kegiatan pembelajaran lingkungan hidup, peserta didik melakukan kegiatan upaya perlindungan dan pengelolaan lingkungan hidup.

c. Kegiatan lingkungan berbasis partisipatif : melibatkan berbagai pihak dalam kegiatan pemeliharaan lingkungan (masyarakat, pemerintah, swasta, sekolah lain).

d. Pengelolaan sarana pendukung ramah lingkungan: air bersih, tanaman/taman, pengkomposan, pengelolaan sampah.

Dari keempat komponen tersebut yang bisa diprioritaskan adalah komponen nomor "c" dan "d" karena melihat MI Muhammadiyah Jagalan memulai kegiatan menuju Madrasah Adiwiyata dari dasar persepsi berupa melakukan "deklarasi menuju madrasah adiwiyata bagi MI Muhammadiyah Jagalan Kabupaten Magelang. Adapun redaksi hasil kesepatan, meliputi:

a. Visi, misi, tujuan dan sasaran prodi PGMI, FAI UMMgl, Anggaran Dasar Muhammadiyah.

b. Visi, misi, tujuan dan sasaran MI Muhamamdiyah Jagalan.

c. Komitmen warga sekolah, pimpinan cabang Muhammadiyah Kecamatan Salam, stakeholder/komite madrasah dan perguruan tinggi: Universitas Muhammadiyah Magelang Program Studi Pendidkan Guru Madrasah Ibtidaiyah untuk menambah sumber daya kerjasama dan promosi bagi MI Muhammadaiyah Jagalan.

d. Daya dukung sarana prasarana lingkungan MI Muhammadiyah Jagalan.

e. Pernyataan kesiapan MI Muhamamdiyah Jagalan Kabupaten Magelang dalam mewujudkan inspirasi menuju madrasah unggulan bidang madrasah adiwiyata.

Tahap 2 (Implementasi Multidirectional Cyrcle Model)

Kegiatan relationship antara elemen-elemen yang terlibat (human resources) dalam upaya optimalisasi agar tujuan organisasi dapat tercapai lebih cepat dari sebelumnya. Implementasinya pada penelitian ini dirancang dalam satu model yang dinamakan Multidirectional circlemodel yang dilaksanakan melalui Focus Group Discussion (FGD).

Adapun kegiatan yang dilakukan, sebagai berikut :

a. Kegiatan lingkungan berbasis partisipatif; peneliti melibatkan berbagai pihak dalam kegiatan pemeliharaan lingkungan, akademisi dari Prodi Pendidikan Guru MI Universitas Muhammadiyah Magelang, Pimpinan Cabang Muhammadiyah Salam Kabupaten Magelang, Komite Madrasah/Stakeholder, Dinas Lingkungan Hidup Kabupaten Magelang. Untuk realisasi program kerja berupa menyediakan SDM guna pelaksanaan program kegiatan dan proses pemeliharaan, mengundang narasumber untuk pendampingan dan evaluasi program kegiatan, penyedia sarana dan prasarana dan bibit tamanan.

b. Pengelolaan sarana pendukung ramah lingkungan; program yang direncanakan adalah pengelolaan air bersih, tanaman/taman, pengkomposan. pengelolaan sampah. Untuk 
realisasi kerja berupa penyediaan tanaman/taman pengolahan sampah pengkomposan dengan petugas pelaksanakelas rendah dengan mananam tanaman Obat didampingi wali kelas 1-3, dan kelas tinggi dengan menanamsayuran didampingi wali kelas 4-6.

Berikut target luaran dalam implementasi multi directioal cycle model menuju Madrasah adiwiyata :

a. Perencanaan, jenis kegiatan berupa persamaan persepsi dan membuat agenda kegiatan, dilaksanakan hari sabtu, 20 Mei 2017 dengan penangungjawab pihak MI Muhamadiyah Jagalan, Peneliti, MajelisPimpinan Cabang Muhammadiyah Pendidikan Dasar dan Menengah Kabupaten Magelang.

b. Pelaksanaan, jenis kegiatan, a) menanam tanaman hias, sayur/buah, obat-obatan (Kunyit, Lengkuas, Serai, Belimbing Wuluh, Seledri, Temu Lawak, Burowali, Kumis Kucing, Daun Sirih, Jahe, Kencur). (kebun kelas rendah; kebun kelas atas; kebun guru karyawan), dilaksanakan tanggal 22-29 Mei 2017, dengan penangung jawab wali kelas 1-6 (kelas rendah dan kelas tinggi) MI Muhammadiyah Jagalan Kabupaten Magelang. b) Pengolahan sampah: bank sampah an-organikdengan melibatkan siswa, guru, karyawan, dilaksanakan 15 Juni 2017, dengan penanggungjawab kepala Madrasah dan wali kelas.

c. Evaluasi, yaitu mengukur ketercapaian program yang dilaksanakan (dilihat dari deksripsi kerja awal (bercocok tanam, pengawasan, perlindungan, dan hasil pembibitan tanaman sekolah), dilaksanakan 20 Juni 2017, dengan penanggungjawab pengelola Madrasah (Guru dan Kepala Madrasah), Peneliti, Majelis Pimpinan Cabang Muhammadiyah Pendidikan Dasar dan Menengah, Komite Madrasah/Stakeholder.

Tahap 3 (Hasil Tindakan)

Dalam proses pelaksanaan, bisa digambarkan dalam langkah kegiatan-kegiatan sebagai berikut :

a. Workshop madrasah adiwiyata: penyaman persepsi tentang sekolah/madrasah adiwiyata melalui workshop sosialisasi yang dilakukan oleh akadmisi dari Prodi Pendidikan Guru MI Universitas Muhammadiyah Magelang, Majelsis Pimpinan Cabang Muhammadiyah Pendidikan Dasar dan Menegah Kabupaten Magelang, Komite Madrasah/Stakeholder, Dinas Lingkungan Hidup Kabupaten Magelang.

b. Persiapan alat : mempersiapkan sarana alat pendukung, seperti cat (warna biru, kuning), kuas, minyak cat, plastik botol aqua, ban bekas, kaleng cat bekas, pot bunga, pipa (paralon) dengan diameter $10 \mathrm{~cm}$ dan $15 \mathrm{~cm}$, kayu penyangga, bibit tanaman sayuran, tanaman herbal, tanah. yang dalam prosesnya dilakukan cocok tanam dengan menggunakan bahan fisik yang tidak bermanfaat dan tidak bisa di recylce menuju reuse. 
c. Bercocok tanam dan pengelolaan bak sampah : semua warga sekolah (siswa, guru, dan kepala sekolah) sebagai pelaku dalam mewujudkan Madrasah adiwiyata bekerjasama dalam pelaksanaan cocok tanam dengan memanfaatkan paralon, pot bunga bekas, ban bekas, kantong plastik bekas minak goreng, polibek yang bertujuan untuk perlindungan dan penegelolaan lingkungan hidup di MI Muhammadiyah Jagalan Kabupaten Magelang. Dalam pengelolaan bak sampah, MI Muhammadiyah Jagalan telah mensosialisasikan dalam bentuk kepedualian membuang sampah sesuai dengan label "organik dan anorganik", sehingga pada akhirnya Madrasah sudah bisa mengelola bank sampah yang akan diual ke agen sampah yang kemudian hasil dari penjualan dikembalikan ke kas seskolah untuk dimanfaatkan unutk perbaikan dan penambahan sarana prasarana Madrasah.

d. Tahapan evaluasi : Adapun hasil yang dilakukan melalui proses awal hingga perencanaan, pelaksanaan tindakan, dan evaluasi memberikan kesimpulan dengan hasil yang maksimal contoh : MI Muhammadiyah sudah membuat program "Market Day" yang tujuannya untuk melatih siswa dalam kemandirin serta mendidik jiwa entreprenuership siswa.

\section{Refleksi Pelaksanaan "Menuju Madrasah Adiwiyata".}

a. Komitmen yang sudah disepakati pada awal workshop sosialisasi menuju Madrasah adiwiyata, menjadikan Madrasah Ibtidaiyah Muhamamdiyah Jagalan Kabupaten Magelang untuk mendeklarasikan menjadi Madrasah Adiwiyata yang dalam prosesnya berdampak positif terhadap lingkungan Madrasah terlebih pada lingkungan sekitar Madrasah, sehingga menjadikan Madrasah ini sebagai Madrasah teladan dalam pengembangan potensi Madrasah bidang non-akademik.

b. Pelaksanaan program Madrasah adiwiyata sangatlah efektif karena mendapatkan dukungan penuh dari (kepala madrasah, guru madrasah, siswa MI, Majelis Pimpinan Cabang Muhammadiyah Pendidikan Dasar dan Menengah Kabupaten Magelang, Komite Madrasah/Stakeholder, Dinas Lingkungan Hidup Kabupaten Magelang), sehingga terbangun sebuah kerjasama yang apik, ini bisa dibuktikan (hasil dokumentasi) dengan melihat dari hasil proses pelaksanaan tindakan.

c. Dengan adanya program menuju Madrasah adiwiyata memberikan dapat yang maksimal bagi Madrasah Ibtidayah Muhamamdiyah dalam merencanakan program lebih baik yang terintegrasi dengan Madrasah Adiwiyata dalam pelaksanan pilot project pada tahun pelajaran selanjutnya. 


\section{SIMPULAN}

Berdasarkan data dan analisisnya yang sudah dilakukan, maka dapat diberikan kesimpulan sebagai berikut :

1. Implementasi multi-directional circle model dalam mewujudkan Madrasah Ibtidaiyah Adiwiyata sangatlah efektif karena bisa menggugah semangat MI Muhammadiyah Jagalan untuk mengembangkan potensi keunggulan prestasi madrasah di bidang non-akademik bagi seluruh komponen sekolah menuju madrasah adiwiyata.

2. Upaya untuk mewujudkan Madrasah Ibtidaiyah Adiwiyata di Kabupaten Magelang adalah dengan langkah-langkah sebagai berikut : a) melakukan workshop pendampingan, b) penandatangan kesepahaman deklarasi madrasah adiwiyata dengan melibatkan akademisi dari prodi PGMI UM Magelang, Majelis Pimpinan Cabang Muhammadiyah Pendidikan Dasar dan Menengah Kabupaten Magelang, Kepala MI Muhammadiyah Jagalan), c) realisasi kegiatan dengan penanaman tanaman, pengelolaan bank sampah, perawatan tanaman sehingga trejadi proses integrasi program kerja, 4) evaluasi program adiwiyata yang akan dilanjutkan partisifasi dalam perlindungan lingkungan madrasah.

\section{DAFTAR PUSTAKA}

Carly, R. A. (2009). Leadership in Green Schools: School Principals as Agents of Social Responsibility, Disertasi: The Pennsylvania State University, Pennsylvania.

Departemen Agama RI. (2008). Al-Qur'an dan terjemahannya. Bandung: Diponegoro

Desfandi, M. (2015). Mewujudkan Masyarakat Berkarakter Peduli Lingkungan Melalui Program Adiwiyata.Sosio Didaktika: social science education journal, 2(1), 31-37

Muhaimin. (2002). Paradigma Pendidikan Islam. Bandung: Remaja Rosdakarya.

Muhaimin, dkk. (2009). Manajemen Pendidikan Aplikasinya dalam Penyusunan Rencana Pengembangan Sekolah/Madrasah. Jakarta: Kencana.

Pratomo, S. dan Barlia, L. (2006). Bahan Ajar MandiriBasic Pendidikan Lingkungan. Bandung: UPI Press.

Rahmah, Y. D. (2015). Implementasi Program Sekolah Adiwiyata (Studi pada SDN Manukan Kulon III/540 Kota Surabaya). Jurnal Administrasi Publik, 2(4), 453-757

Salinan Peraturan Menteri Negara Lingkungan HidupNomor 05 tahun 2013 tentang Pedoman Pelaksanaan Program Adiwiyata.

Sibel, O., Ertepinar, H., dan Saglam, N. (2012). "Can Eco-Schools Improve Elementary School Students' Environmental Literacy Levels?” Asia- Pacific Forum on Science Learning and Teaching. 13(2).

Sungkowo. (2005). Konsep Pendidikan Lingkungan Hidup Pada Jalur Pendidikan Dasar dan Menengah. Jakarta: Dikdasmen.

Tim Adiwiyata Tingkat Nasional. (2012). Buku Panduan Adiwiyata Sekolah Pedulai dan Berbudaya Lingkungan, Kerjasama Kementerian Lingkungan Hidup dan Kementerian Pendidikan dan Kebudayaan. 